\begin{tabular}{cc|c}
\hline Tar. Bil. Der. & Tarım Bilimleri Dergisi & Journal of Agricultural Sciences \\
& $\begin{array}{c}\text { Dergi web sayfası: } \\
\text { www.agri.ankara.edu.tr/dergi }\end{array}$ & Journal homepage: \\
& www.agri.ankara.edu.tr/journal
\end{tabular}

\title{
Effect of the Application of Foliar Selenium on Canola Cultivars as Influenced by Different Irrigation Regimes
}

\author{
Mandana HEMMATI ${ }^{\mathrm{a}}$, Babak DELKHOSH ${ }^{\mathrm{a}}$, Amir Hossein Shirani RAD ${ }^{\mathrm{b}^{*}}$, ,horban Noor MOHAMMADI $^{\mathrm{a}}$ \\ ${ }^{a}$ Department of Agronomy, Science and Research Branch, Islamic Azad University, Tehran, IRAN

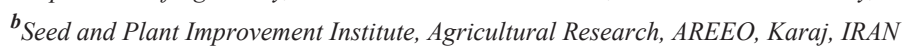

\section{ARTICLE INFO}

Research Article

DOI: 10.15832 /ankutbd.424899

Corresponding Author: Amir Hossein Shirani RAD, E-mail: shiranirad96@gmail.com, Tel: +98 (912) 2649061

Received: 18 May 2018, Received in Revised Form: 30 July 2018, Accepted: 04 August 2018

\begin{abstract}
Selenium $(\mathrm{Se})$ is an essential micro-nutrient element for animals and human, which also has some beneficial roles in many plant species. This study aimed to evaluate the application of foliar $S e$ on canola cultivars under different irrigation regimes. The study was carried out in two consecutive years, in the form of a factorial split plot experiment, based on an RCB design with three replications. Sodium selenate solution was sprayed on the leaves of 6 winter canola exposed to 3 different irrigation regimes. The results revealed that most of the studied traits were affected by foliar selenium, especially seed yield, seed oil yield, leaf proline content and leaf chlorophyll a content. Under drought stress conditions, foliar selenium caused a significant increase in seed yield, seed oil yield, and the relative water content of leaves. According to partial regression analysis, foliar selenium changed the nature of relationships governing the traits, especially under drought stress conditions. The results showed that, selenium reduced the effects of drought stress through improving the relative water content of the leaves. Therefore, foliar selenium can be a useful strategy to achieve sustainable agriculture, especially under water deficit conditions.

Keywords: Irrigation regime; Partial regression; Rapeseed; Seed yield; Sodium selenate
\end{abstract}

(C) Ankara Üniversitesi Ziraat Fakültesi

\section{Introduction}

Iran, with an average annual rainfall of $240 \mathrm{~mm}$, is located in the arid and semi-arid belt regions of the world. More than $60 \%$ of Iranian lands is located in the arid and semi-arid regions in which, water scarcity is the most important limiting factor for agricultural activities (Modarres \& de Paulo Rodrigues da Silva 2007). Studies have shown that under water deficit condition, oxidative stress reduces plant growth, respiration, and photosynthesis through damaging cellular compounds, such as carbohydrates, lipids, nucleic acids, and proteins (Ahmad et al 2016).

Canola (Brassica napus L.) is one of the world's leading edible oil crops which favors human consumption due to its high oil and low saturated fat content (Turinek et al 2016). Studies have shown water scarcity has an undesirable effect on most of the morphological and agronomic characteristics of this plant (Ullah et al 2012; Badrooj et al 2016; Jaberi et al 2016; Pavlista et al 2016; Said-Al Ahl et al 2016). Most crop plants are sensitive to drought 
stress, especially at flowering, pollination, and seed filling stages (Thomas et al 2004). Masoud Sinaki et al (2007) reported that the highest decrease in canola performance was observed during water deficit at the pod development stage.

Selenium $(\mathrm{Se})$ is an essential micro-nutrient element for animals and human (Woo \& Lim 2017). Although its necessity for higher plants is still unproven, however it is still of interest to biologists due to its beneficial role in many plant species (ElRamady et al 2015). Studies have shown that Se plays a beneficial role in plants through enhancing growth, reducing damage caused by oxidative stress, enhancing chlorophyll content under light stress, stimulating senesce to produce antioxidants, and improving plant tolerance to drought stress by regulating water status (Ahmad et al 2016). As reported by Hasanuzzaman \& Fujita (2011), selenium conferred enhanced tolerance to drought stress in rapeseed seedlings. As a secondary Se accumulator, canola takes up $\mathrm{Se}$ in proportion to the amount of Se available in the soil (White et al 2004). Commercial selenium-enriched fertilizers are in the forms of selenate and selenite. Recently, Deng et al (2017) showed that a greater accumulation of $\mathrm{Se}$ was obtained when selenate-base fertilizers was used. Also, foliar spray of $\mathrm{Se}$ was found to be a more economical and effective method than when incorporated with soil (Wang et al 2017).
The present experiment aims to determine the effect of foliar sodium selenate on some agrophysiological traits of canola under drought stress conditions. The experiment is based on the assumption that foliar selenium can possibly alleviate limiting effects due to drought stress.

\section{Materials and Methods}

\subsection{Experimental design}

The experiment was carried out at the research farm of Seed and Plant Improvement Institute, Karaj, Iran (latitude $35^{\circ} 59^{\prime} \mathrm{N}$, longitude $50^{\circ} 75^{\prime} \mathrm{E}$, altitude $1313 \mathrm{~m}$ above sea level) during two consecutive years (2014-15 and 2015-16). The soil texture was clay loam with 0.64 of organic matter (Table 1). Studied factors included i) irrigation regimes and ii) foliar application of sodium selenate and six winter canola genotypes i.e. Ahmadi, SW102, Okapi, GKH2624, GK-Gabriella, and Elvis. The factors were arranged as a factorial split plot based on a randomized complete block statistical design with three replications. The levels of irrigation regimes and foliar application of sodium selenate were randomly assigned to main plots, while canola genotypes were randomly distributed among sub plots.

Table 1- Physico-chemical parameters of the experimental field soil

\begin{tabular}{ccccccccc}
\hline $\begin{array}{c}\text { Depth } \\
(\mathrm{cm})\end{array}$ & $\begin{array}{c}\text { Potassium } \\
\left(\mathrm{mg} \mathrm{kg}^{-1} \text { of soil }\right)\end{array}$ & $\begin{array}{c}\text { Phosphorus } \\
\left(\mathrm{mg} \mathrm{kg}^{-1} \text { of soil }\right)\end{array}$ & N\% & Clay\% & Silt\% & Sand\% & $\begin{array}{c}E c \\
\left(\mathrm{Ds} \mathrm{m}^{-1}\right)\end{array}$ & \begin{tabular}{c} 
PH \\
\hline $0-30$
\end{tabular} \\
\hline 276 & 154 & $0 / 06$ & 42 & 29.33 & 29 & 1.72 & 7.75 \\
\hline
\end{tabular}

On October $2^{\text {nd }}$ of each crop year, the seeds were sown at a depth of 1 to $1.5 \mathrm{~cm}$, with a density of 100 seeds per square meter. Each plot, with an area of $10.8 \mathrm{~m}^{2}$, consisted of 6 rows, which were $6 \mathrm{~m}$ long and $30 \mathrm{~cm}$ apart. The seeds were planted on rows and were spaced $4 \mathrm{~cm}$ apart. The distance between the plots and blocks was $2.4 \mathrm{~m}$ and $7 \mathrm{~m}$, respectively. Two lateral lines were considered as margins and only the 4 middle lines were used for sampling and measuring of traits. Nitrogen, phosphorous and potassium chemical fertilizers were added to the soil at the rate of 150: $60: 50 \mathrm{~kg} \mathrm{ha}^{-1}$, respectively. Phosphorous and potassium fertilizers together with one-third of nitrogen were added to the soil concurrent with seed sowing, while the remaining two-third of nitrogen was distributed equally at the beginning of stem elongation and flowering stages. Weed control was done mechanically and 
chemically. Plots were irrigated by furrow method until the reproductive stage.

\subsection{Selenium and drought treatments}

On April $27^{\text {th }}$ after the planting year, sodium selenate solution $\left(\mathrm{Na}_{2} \mathrm{SeO}_{4}\right)$ was sprayed on the leaves of the crop in two concentrations of Se1: 0 and Se2: 30 $\mathrm{g} \mathrm{L}^{-1}$. Three irrigation regimes were considered as drought stress treatment levels including I1: normal irrigation I2: irrigation cut off from flowering stage (A week after selenium spray, concurrent with the emergence of $50 \%$ of flowers) and I3: irrigation cut off from pod development stage (three weeks after selenium spray, concurrent with the emergence of $50 \%$ of pods).

\subsection{Studied traits}

Studied traits included plant height $(P H)$, number of pods plant ${ }^{-1}(N P P)$, number of seeds pod ${ }^{-1}$ of main stem (NSPMS), number of seeds pod $^{-1}$ of lateral branches (NSPLB) thousand-seed weight $(T S W)$, seed yield $(S Y)$, see oil yield (SOY), the relative water content of leaves $(R W C)$, leaf proline content $(L P C)$, leaf chlorophyll a content (Chla), and leaf chlorophyll b content $(C h l b)$. To measure physiological traits such as chlorophyll and proline content of the leaves, 10 leaves were randomly selected from the middle lines of each plot. Also, to measure the agronomic traits, 10 plants were randomly selected from the middle lines of each plot. Stress intensity (SI) was calculated using the Equation proposed by Fischer \& Maurer (1978) as:

$$
S I=1-\left(\frac{\overline{Y_{s}}}{\overline{Y_{p}}}\right)
$$

Where; $\bar{Y}_{s}$ and $\bar{Y}_{p}$ are mean yield under stress and non-stress conditions, respectively. The leaf relative water content was determined as follows:

$$
R W C \%=\frac{F W-D W}{F W} \times 100 \text { (Ritchie et al 1990) }
$$

Where; $F W$ and $D W$ are defined as the fresh weight and the dry weight of leaf. The proline content of the leaves was estimated as described by Bates et al (1973). Leaf chlorophyll content was measured according to Arnon (1949).

All the data were subjected to combined analysis of variance (ANOVA) using General Liner Model procedure in SAS software version 9.1.3, 2003, SAS Institute Inc., Cary, NC, USA. Means were compared at a 0.05 probability level. Partial regression coefficients were calculated in Microsoft Excel software based on the method described by Akintunde (2012).

\section{Results and Discussion}

Combined analysis of variance (ANOVA) revealed that different irrigation regimes had significant effects on all studied traits except for $T S W$ and $C h l b$. Also, selenium spray significantly affected $P H$, NSPMS, NSPLB, SY, SOY, LPC, and Chla. Selenium by irrigation interaction effect was statistically significant for $S Y, S O Y$, and $R W C$. Furthermore, variation due to genotype was significant for all traits (data not shown).

\subsection{Effects due to irrigation regime}

Drought is a form of environmental stress that affects the physiological and biochemical processes in plants (Ahmad et al 2016). In general, mean trait values were found to be higher in the second year of the experiment except for $L P C$ and $R W C$ (Table 2).

Estimation of stress intensity revealed that, in both years, irrigation cut off from flowering caused more stress compared to irrigation cut off from pod development stage. In most references, accumulation of reactive oxygen species (ROS) has been known to be the main cause of devaluation of traits under drought stress (Feng et al 2013). Therefore, it can be concluded that irrigation cut off from flowering stage caused more accumulation of $R O S$ which resulted in a further decrease in mean trait values. Increase in stress intensity affected most of the studied traits. For example, irrigation cut off from flowering caused a remarkable decrease in $S Y$ up to $46.09 \%$ compared to the control plants (Table 2). This result was in contrast with Masoud Sinaki et al (2007) who 
stated that most of the reduction in canola yield was achieved when drought stress occurred during pod development stage. Water deficit significantly affects crop evapotranspiration and yield. According to Léllis et al (2017), when water supply does not meet crop water requirements, actual evapotranspiration will fall below the maximum evapotranspiration. In such circumstances, the response of crop yield to water deficit is a function of the proportion of relative yield decrease to relative evapotranspiration deficit, which is variable depending on the growth stage when water deficit occurs (Shirani Rad et al 2013). In the case of water shortages, dry matter reduction can be due to decreased cellular turgor pressure and biochemical restrictions, resulting in lower leaf chlorophyll content and photosynthesis (Shirani Rad \& Abbasian 2011).

Irrigation cut off from flowering reduced $S O Y$ up to $49.32 \%$ compared to control plants (Table 2). Seed oil yield is a function of seed oil percentage and seed yield. Furthermore, changes in the content of seed oil in modified cultivars is low, thus the $S Y$ has the highest effect on SOY. Therefore, selecting the cultivars for higher $S Y$ will lead to increase in SOY.

Plant height also declined up to $32.11 \%$ when the irrigation was cut off from flowering (Table 2). Reduction of $P H$ is a consequence of reduced chlorophyll content and photosynthesis area, increased energy consumed by the plant to absorb water, increased protoplasm density, change in respiration pathways, the activation of the pentose phosphate route and/or the reduction of root volume, etc (Moaveni et al 2010).

The cut off of irrigation from the flowering stage caused a decrease in the number of pods per plant by up to $56 \%$. It seems that under the stress of water shortage, reduction of the number of pods in the higher-order branches plays a role in decreasing the number of pods per plant (Shirani Rad et al 2013). Research has shown that the flow of water to the leaf depends on the presence of water potential gradients between the xylem and the leaves, so that reduction in the water potential of xylem reduces the water potential gradient between the xylem and the leaf. Therefore, the number of seeds per plant under water deficit stress is decreased (Afkari Bajeh Baj 2012).

The results showed that water deficit reduced $T S W$ significantly. Under drought stress conditions, photosynthesis rate decreases due to chlorophyll drop and consequently, reducing the storage and accumulation of photosynthetic material in the seeds causes a reduction in TSW. Also, reduction in seed weight is a consequence of the declines in the number of seeds plant ${ }^{-1}$ as well as the number of seeds $\operatorname{pod}^{-1}$.

Statistically, drought stress led to a nonsignificant decrease in Chlb, showing a relative resistance to the drought stress applied in this study (Table 2). Compared to other studied traits, the highest reduction due to drought was observed for NPP and Chla (54.4\% and 50.88\%, respectively, Table 2). Previous studies indicated that drought stress causes a significant decline in leaf chlorophyll content. Under drought stress conditions, decrease of photosynthetic pigments content is a common symptom which mainly results from damage to chloroplasts caused by ROS (Mafakheri et al 2010). Moreover, the observed decline in Chla was almost two that of Chlb. This result was in agreement with Ghorbanli et al (2013).

Drought stress reduced the relative water content of the leaves. An increase in drought caused a further decline in $R W C$. As an indicator of water status in plants, $R W C$ reflects the balance between water supply to the leaf tissue and transpiration rate. Therefore, it seems that there would be a significant correlation between $R W C$ and relative yield loss. In our experiment, this correlation was high, negative, and significant at 0.01 probability level $(-0.929 * *)$. Soltys-Kalina et al (2016) also confirmed the existence of such a significant and negative correlation. The $L P C$ increased from 11.80 at I1 to $21.02 \mu \mathrm{M} \mathrm{g}^{-1}$ at I3 level, showing an increase of up to $78.13 \%$ (Table 2). As one of the most important osmolytes, proline accumulation protects the chloroplasts against destruction, consequently 


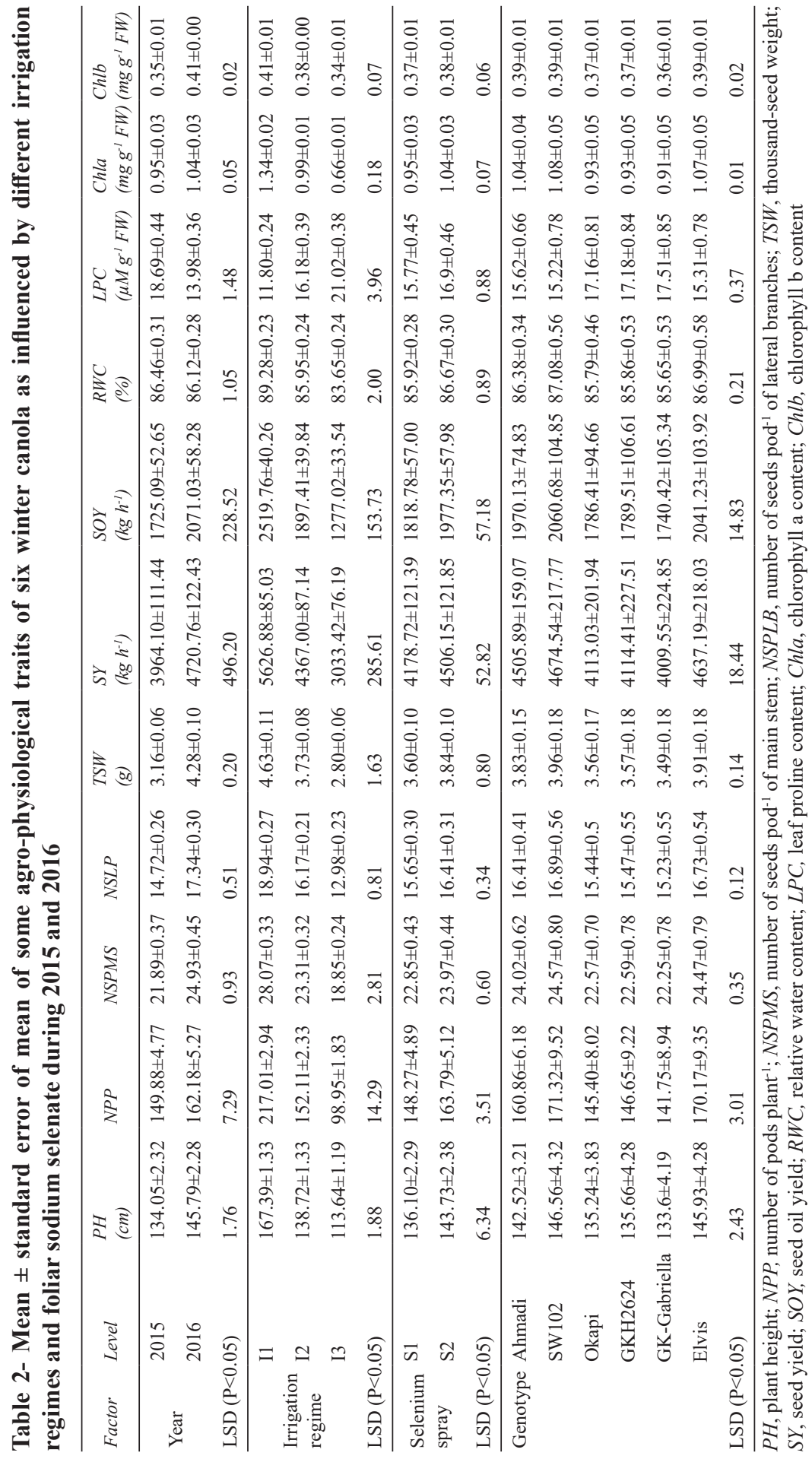


preventing chlorophyll depletion under stress conditions. Therefore, proline accumulation is directly related to the degree of resistance to drought stress (Mwenye et al 2016).

\subsection{Effects due to foliar selenium application}

Physiological and antioxidant properties of $\mathrm{Se}$ drew the attention of scientists and led to various researches being conducted in this area. In this study, most of the studied traits were affected by foliar selenium. Selenium spray remarkably increased NPP, SOY, Chla, and SY by up to $10.47,8.72$, 8.70 , and $7.84 \%$, respectively. Various literatures have noted the increase of leaf chlorophyll content under the influence of selenium. In accordance with the results of this study, Mozafariyan et al (2017) reported an increase in chlorophyll content of tomato leaves when the plants were fed with 7 and $10 \mu \mathrm{M}$ of selenium. Feng et al (2013) believed that the addition of $\mathrm{Se}$ to the growth substrates can reduce the excess ROS generation, especially of $\mathrm{O}_{2}$ - and/or $\mathrm{H}_{2} \mathrm{O}_{2}$, in plants subjected to stress. In chloroplasts, $\mathrm{Fe}-\mathrm{S}$ clusters have a vital role for the operation of cytochrome B/F complex (Raven et al 1999). On the other hand, formation of $\mathrm{Fe}$-Se clusters may occur under Se supplementation which plays an important role in the electron transfer chain, the emergence and quenching of ROS and the responses of antioxidants in stressed plants (Feng et al 2013). Although, the addition of appropriate levels of $\mathrm{Se}$ can increase the chlorophyll content, however, more selenium levels have had stressful effects on Chlorella vulgaris leading to loss of chlorophyll content (Chen et al 2005).

Also, LPC significantly increased up to $7.21 \%$ (Table 2). Increase in the proline content of leaves under the influence of foliar selenium has been earlier reported (Djanaguiraman et al 2005). According to El-Ramady et al (2015), Se acts as an antioxidant and as a result inhibits lipid peroxidation via increased levels of thiols and GSH. They also suggested that, $\mathrm{Se}$ activates plant protective mechanisms, thereby alleviating oxidative stress, and improving heavy metals or trace elements uptake in higher plants. Nevertheless, despite the numerical increase, no significant improvement was observed for $T S W$, $R W C$, and Chlb (Table 2).

As shown in Figure 1, under drought stress conditions, foliar selenium alleviated the adverse effects of drought stress on some important traits. At the second level of the irrigation regime (i.e. when the irrigation was cut off from flowering stage), the SY measured for selenium-sprayed plants showed a significant increase of up to $12.48 \%$. Likewise, at the third level of the irrigation regime (i.e. irrigation
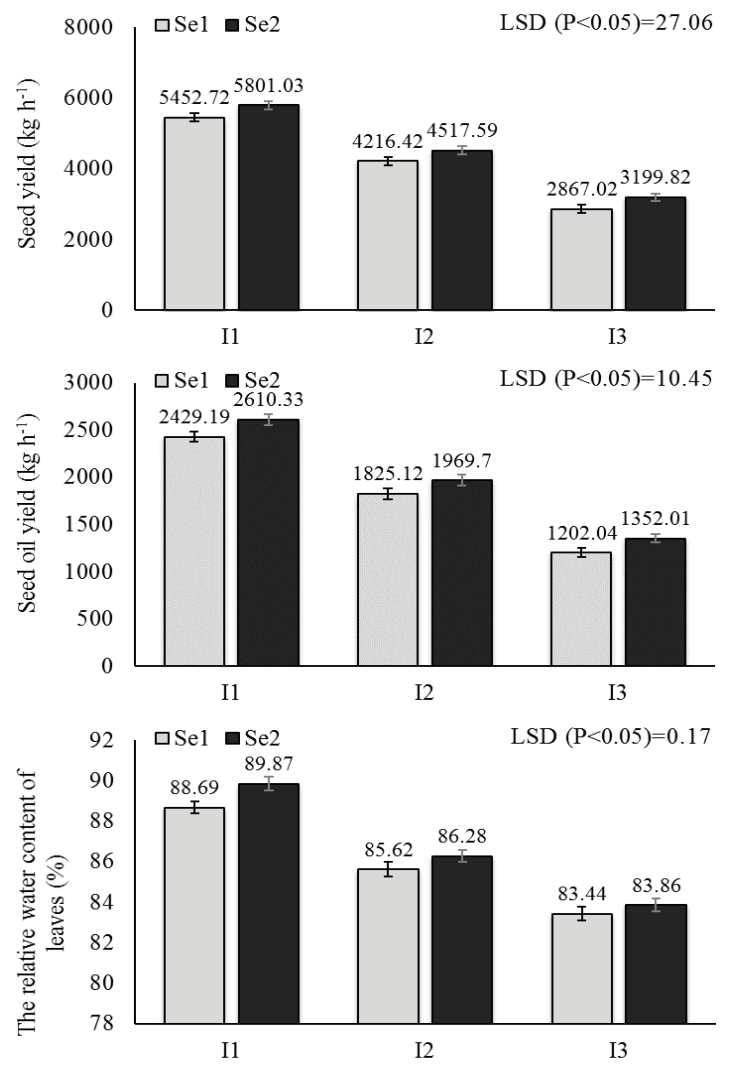

Figure 1- Mean comparison of seed yield (A), oil yield $(B)$, and the relative water content of leaves (C) of six winter canola as influenced by different irrigation regimes and foliar sodium selenate (Se1, no selenium (control); Se2, selenum solution (30 g $\left.\mathbf{L}^{-1}\right)$ spryaed on leaves; I1, normal irrigation; I2, irrigation cut off from pod development stage; I3, irrigation cut off from flowering stage) 
cut off from pod development stage), foliar selenium led to an increase of up to $7.92 \%$ for $S Y$. A similar trend was observed for $S O Y$ and $R W C$ (Figure 1). Increase in $R W C$ for selenium-fed plants could have resulted from the improvement of plant water management or a significant interaction between the effects of water deficit and Se on respiratory potential (Hasanuzzaman \& Fujita 2011). Similar findings have been reported in wheat (Nawaz et al 2015) and rice (Xu \& Hu 2004).

\subsection{Partial regression coefficients}

Partial regression coefficients were estimated to determine the relative importance of traits affecting SY (Table 3). Considering that the data were standardized before the regression analysis, therefore, the regression coefficients were comparable with each other and hence, the higher coefficient represents the greater weight of the corresponding traits.

I1, normal irrigation; I2, irrigation cut off from pod development stage; I3, irrigation cut off from flowering stage; Se1, no selenium (control); Se2, exposed to foliar sodium selenate solution $(30 \mathrm{~g}$ $\left.\mathrm{L}^{-1}\right)$; $P H$, plant height; $N P P$, number of pods plant ${ }^{-1}$; NSPMS, number of seeds $\operatorname{pod}^{-1}$ of main stem; $N S P L B$, number of seeds pod ${ }^{-1}$ of lateral branches; $T S W$, thousand-seed weight; $R W C$, relative water content; $L P C$, leaf proline content; Chla, chlorophyll a content; Chlb, chlorophyll b content

According to the results, the direct effects of traits on $S Y$ varied when the plants were exposed to foliar selenium. At I2-Se1 level, the highest positive direct effects on $S Y$ belonged to Chla and NSPMS while, at I2-Se2 level, PH, Chla, RWC and NSPLB had the highest positive direct effects (Table 3 ). Although $P H$ is a vegetative trait, it should be noted that increased $P H$ causes an increase in $N P P$ which leads to increased $S Y$. According to these results, foliar selenium seems to increase the $R W C$ which leads to decrease in the intensity of drought stress. Moreover, at I3-Se1 level, Chla, together with TSW had the highest positive direct effects on $S Y$ while, at I3-Se2 level, Chla, RWC, PH and NSPLB had the highest positive direct effects on $S Y$ (Table 3). As reported by Sabaghnia et al (2010), TSW was one of the most important traits related to $S Y$ under both normal and water-stressed conditions.

According to the results, under the influence of drought stress, selenium spray application caused $R W C$, Chla, NSPLB, and $P H$ to have a direct and important effect on $S Y$. Consequently, the selection of these traits can be useful in plant breeding programs.

These results imply that under drought stress, selenium spray varied the nature of the causal relationship between $S Y$ and other studied traits.

Table 3- Partial regression coefficients of seed yield over some agro-physiological traits in six winter canola as influenced by different irrigation regimes and foliar sodium selenate

\begin{tabular}{|c|c|c|c|c|c|c|}
\hline \multirow{2}{*}{ Model } & \multicolumn{2}{|c|}{$I 1$} & \multicolumn{2}{|c|}{$I 2$} & \multicolumn{2}{|c|}{$I 3$} \\
\hline & $\mathrm{Sel}$ & $\mathrm{Se} 2$ & $\mathrm{Sel}$ & $\mathrm{Se} 2$ & $\mathrm{Sel}$ & $\mathrm{Se} 2$ \\
\hline Intercept & 0.000 & 0.000 & 0.000 & 0.000 & 0.000 & 0.000 \\
\hline PH & 0.285 & 0.381 & 0.057 & 0.305 & -0.278 & 0.218 \\
\hline$N P P$ & -0.268 & 0.406 & 0.083 & -0.551 & -0.903 & -0.050 \\
\hline NSPMS & 0.014 & 1.014 & 0.441 & 0.164 & 0.013 & -0.442 \\
\hline$N S P L B$ & -0.182 & -0.306 & -0.749 & 0.279 & 0.133 & 0.210 \\
\hline$T S W$ & 0.250 & -0.025 & 0.198 & -0.226 & 0.956 & 0.133 \\
\hline$R W C$ & 0.095 & -0.127 & -0.198 & 0.277 & 0.254 & 0.190 \\
\hline$L P C$ & -0.388 & 0.001 & -0.294 & -0.427 & 0.041 & -0.374 \\
\hline Chla & 0.474 & -0.545 & 0.464 & 0.323 & 0.937 & 0.448 \\
\hline Chlb & -0.084 & 0.150 & 0.168 & -0.113 & 0.138 & -0.092 \\
\hline
\end{tabular}

Tarım Bilimleri Dergisi - Journal of Agricultural Sciences 25 (2019) 309-318 
It seems that the relationships between traits were affected by the strategies and mechanisms adopted by the plant to deal with drought. Therefore, regression coefficients were variable among different levels of the drought stress.

\subsection{Cluster analysis of genotypes}

Cluster analysis categorized the genotypes into two groups each with three members (Figure 2). Cluster I consisted of 3 genotypes including Ahmadi, Elvis, SW102, and cluster II consisted of genotypes GKGabriella, GKH2624, and Okapi. Except for $L P C$, trait mean values for cluster I were found to be higher compared to cluster II (Table 4). Based on this result, cluster I genotypes are recommended for cultivation compared to genotypes clustered in group II.

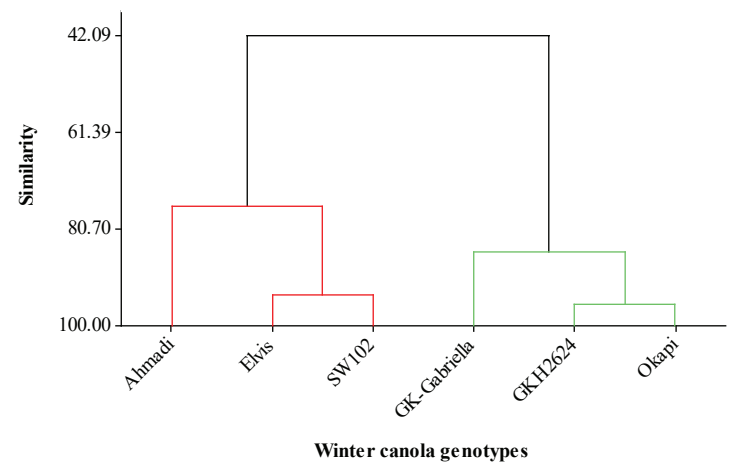

Figure 2- Dendrogram obtained from cluster analysis of six winter canola subjected to different irrigation regimes and foliar sodium selenate during 2015 and 2016

\section{Conclusions}

The results of this study showed that the use of foliar selenium can be considered as a useful strategy to cope with the adverse effects of drought stress in order to achieve sustainable agriculture. Also, genotypes Ahmadi, Elvis, SW102, are recommended for cultivation in semi-arid regions.

\begin{tabular}{|c|c|}
\hline \multicolumn{2}{|c|}{ Abbreviations and Symbols } \\
\hline ANOVA & Analysis of variance \\
\hline Chla & $\begin{array}{l}\text { Leaf Chlorophyll a Content } \mathrm{mg} \mathrm{g}^{-1} \text { of } \\
\text { leaf fresh weight }\end{array}$ \\
\hline Chlb. & $\begin{array}{l}\text { And Leaf Chlorophyll b Content } \mathrm{mg} \mathrm{g}^{-1} \\
\text { of leaf fresh weight }\end{array}$ \\
\hline$L P C$ & $\begin{array}{l}\text { Leaf Proline Content } \mu \mathrm{M} \mathrm{g}^{-1} \text { of leaf } \\
\text { fresh weight }\end{array}$ \\
\hline$N P P$ & Number of Pods Plant ${ }^{-1}$ \\
\hline$N S P L B$ & $\begin{array}{l}\text { Number of Seeds Pod }{ }^{-1} \text { Lateral } \\
\text { Branches }\end{array}$ \\
\hline NSPMS & Number of Seeds Pod ${ }^{-1}$ of Main Stem \\
\hline $\mathrm{PH}$ & Plant Height $(\mathrm{cm})$ \\
\hline$R O S$ & Reactive Oxygen Species \\
\hline$R W C$ & $\begin{array}{l}\text { The Relative Water Content of Leaves } \\
(\%)\end{array}$ \\
\hline $\mathrm{Se}$ & Selenium \\
\hline$S I$ & Stress Intensity \\
\hline SOY & See Oil Yield $\left(\mathrm{kg} \mathrm{h}^{-1}\right)$ \\
\hline$S Y$ & Seed Yield $\left(\mathrm{kg} \mathrm{h}^{-1}\right)$ \\
\hline$T S W$ & Thousand-Seed Weight (g) \\
\hline
\end{tabular}

Table 4- Mean \pm standard error of mean for groups derived from cluster analysis of six winter canola as influenced by different irrigation regimes and foliar sodium selenate during 2015 and 2016

\begin{tabular}{|c|c|c|c|c|c|c|c|c|c|c|c|}
\hline $\begin{array}{l}\text { Cluster } \\
\text { membership }\end{array}$ & $P H$ & $N P P$ & NSPMS & $N S P L B$ & $T S W$ & $S Y$ & $S O Y$ & $R W C$ & $L P C$ & Chla & Chlb \\
\hline $\begin{array}{l}\text { Ahmadi, } \\
\text { Elvis, } \\
\text { SW102 }\end{array}$ & $139.41 \pm 1.80$ & $160.96 \pm 2.66$ & $22.75 \pm 0.21$ & $15.34 \pm 0.14$ & $3.31 \pm 0.04$ & $4224.42 \pm 48.54$ & $1848.40 \pm 25.10$ & $87.04 \pm 0.21$ & $17.73 \pm 0.19$ & $1.02 \pm 0.01$ & $0.36 \pm 0.001$ \\
\hline $\begin{array}{l}\text { GK- } \\
\text { Gabriella, } \\
\text { GKH2624, } \\
\text { Okapi }\end{array}$ & $128.68 \pm 0.60$ & $138.79 \pm 1.49$ & $21.03 \pm 0.10$ & $14.10 \pm 0.07$ & $3.01 \pm 0.02$ & $3703.79 \pm 34.67$ & $1601.78 \pm 15.50$ & $85.88 \pm 0.06$ & $19.64 \pm 0.07$ & $0.88 \pm 0.01$ & $0.34 \pm 0.003$ \\
\hline $\begin{array}{l}\text { LSD } \\
(\mathrm{P}<0.05)\end{array}$ & 5.26 & 8.47 & 0.64 & 0.43 & 0.12 & 165.62 & 81.91 & 0.62 & 0.56 & 0.04 & 0.01 \\
\hline
\end{tabular}




\section{References}

Afkari Bajeh Baj A (2012). Effect of potassium on drought resistance in sunflower (Helianthus annuus L.) cultivars. In: Opara J A, Fakae B B, Berctold G, Zoller U, Oguzor N S, Islam N, Abere SA (eds) International Conference on Agriculture, Science and Engineering (ICASE2012). 3-7 September, Beverly Scientific Organisation, Port Harcourt-Nigeria, pp. 316

Ahmad R, Waraich E A, Nawaz F, Ashraf M Y \& Khalid $M$ (2016). Selenium (Se) improves drought tolerance in crop plants-a myth or fact? Journal of the Science of Food and Agriculture 96(2): 372-380

Akintunde A (2012). Path analysis step by step using excel. Journal of Technical Science and Technologies 1(1): 9-15

Arnon D I (1949). Copper enzymes in isolated chloroplasts. Polyphenoloxidase in Beta vulgaris. Plant Physiology 24(1): 1-15

Badrooj H R, Hamidi A, Rad S \& Hossein A (2016). Effect of drought stress and normal 1rrigation during flowering to maturity of 10 spring oilseed rape (Brassica napus L.) genotypes seed germination. Iranian Journal of Seed Research 2(2): 1-14

Bates L, Waldren R \& Teare I (1973). Rapid determination of free proline for water-stress studies. Plant and Soil 39(1): 205-207

Chen T-F, Zheng W-J, Luo Y, Yang F, Bai Y \& Tu F (2005). Effects of selenium stress on photosynthetic pigment contents and growth of Chlorella vulgaris. Journal of Plant Physiology and Molecular Biology 31(4): 369-373

Deng X, Liu K, Li M, Zhang W, Zhao X, Zhao Z \& Liu X (2017). Difference of selenium uptake and distribution in the plant and selenium form in the grains of rice with foliar spray of selenite or selenate at different stages. Field Crops Research 211: 165-171

Djanaguiraman M, Devi D D, Shanker A K, Sheeba J A \& Bangarusamy U (2005). Selenium-an antioxidative protectant in soybean during senescence. Plant and Soil 272(1): 77-86

El-Ramady H, Abdalla N, Alshaal T, El-Henawy A, Faizy SE-DA, Shams M S, Shalaby T, Bayoumi Y, Elhawat N, Shehata S, Sztrik A, Prokisch J, Fári M, Pilon-Smits E A \& Domokos-Szabolcsy É (2015). Selenium and its Role in Higher Plants. In: Lichtfouse E, Schwarzbauer J, Robert D (Eds) Pollutants in
Buildings, Water and Living Organisms. Springer International Publishing, Cham, pp. 235-296

Feng R, Wei C \& Tu S (2013). The roles of selenium in protecting plants against abiotic stresses. Environmental and Experimental Botany 87: 58-68

Fischer R \& Maurer R (1978). Drought resistance in spring wheat cultivars. I. Grain yield responses. Crop and Pasture Science 29(5): 897-912

Ghorbanli M, Gafarabad M, Amirkian T \& Mamaghani B A (2013). Investigation of proline, total protein, chlorophyll, ascorbate and dehydroascorbate changes under drought stress in Akria and Mobil tomato cultivars. Iranian Journal of Plant Physiology 3: 651658

Hasanuzzaman M \& Fujita M (2011). Selenium pretreatment upregulates the antioxidant defense and methylglyoxal detoxification system and confers enhanced tolerance to drought stress in rapeseed seedlings. Biological Trace Element Research 143(3): 1758-1776

Jaberi H, Lotfi B, Feilinezhad A, Fathi A, Ersi F K \& Abdollahi A (2016). Evaluation of yield and yield components of four winter canola cultivars under drought stress. Advances in Bioresearch 7(5): 27-31

Léllis B, Carvalho D, Martínez-Romero A, Tarjuelo J \& Domínguez A (2017). Effective management of irrigation water for carrot under constant and optimized regulated deficit irrigation in Brazil. Agricultural Water Management 192: 294-305

Mafakheri A, Siosemardeh A, Bahramnejad B, Struik P \& Sohrabi Y (2010). Effect of drought stress on yield, proline and chlorophyll contents in three chickpea cultivars. Australian Journal of Crop Science 4(8): 580

Masoud Sinaki M, Majidi Heravan E, Shirani Rad A, Noormohammadi G \& Zarei G (2007). The effects of water deficit during growth stages of canola (Brassica napus L.). American-Eurasian Journal of Agricultural \& Environmental Sciences 2: 417-422

Moaveni P, Ebrahimi A \& Farahani H A (2010). Studying of oil yield variations in winter rapeseed (Brassica napus L.) cultivars under drought stress conditions. Journal of Agricultural Biotechnology and Sustainable Development 2(5): 71-75

Modarres R \& de Paulo Rodrigues da Silva V (2007). Rainfall trends in arid and semi-arid regions of Iran. Journal of Arid Environments 70(2): 344-355 
Mozafariyan M, Pessarakli M \& Saghafi K (2017). Effects of selenium on some morphological and physiological traits of tomato plants grown under hydroponic condition. Journal of Plant Nutrition 40(2): 139-144

Mwenye O J, Van Rensburg L, Van Biljon A \& Van der Merwe R (2016). The role of proline and root traits on selection for drought-stress tolerance in soybeans: a review. South African Journal of Plant and Soil 33(4): 245-256

NawazF,Ahmad R, Ashraf M, Waraich E \& Khan S (2015). Effect of selenium foliar spray on physiological and biochemical processes and chemical constituents of wheat under drought stress. Ecotoxicology and Environmental Safety 113: 191-200

Pavlista A, Hergert G, Margheim J \& Isbell T (2016). Growth of spring canola (Brassica napus) under deficit irrigation in Western Nebraska. Industrial Crops and Products 83: 635-640

Raven J A, Evans M C \& Korb R E (1999). The role of trace metals in photosynthetic electron transport in O 2-evolving organisms. Photosynthesis Research 60(2): 111-150

Ritchie S W, Nguyen H T \& Holaday A S (1990). Leaf water content and gas-exchange parameters of two wheat genotypes differing in drought resistance. Crop Science 30(1): 105-111

Sabaghnia N, Dehghani H, Alizadeh B \& Mohghaddam M (2010). Interrelationships between seed yield and 20 related traits of 49 canola (Brassica napus L.) genotypes in non-stressed and water-stressed environments. Spanish Journal of Agricultural Research 8(2): 356-370

Said-Al Ahl H A H, Mehanna H M \& Ramadan M F (2016). Impact of water regime and phosphorus fertilization and their interaction on the characteristics of rapeseed (Brassica napus) and fatty acid profile of extracted oil. Communications in Biometry and Crop Science 11: 64-76

Shirani Rad A H \& Abbasian A (2011). Evaluation of drought tolerance in winter rapeseed cultivars based on tolerance and sensitivity indices. Žemdirbyste (Agriculture) 98(1): 41-48
Shirani Rad A, Abbasian A \& Aminpanah H (2013). Evaluation of rapeseed (Brassica napus L.) cultivars for resistance against water deficit stress. Bulgarian Journal of Agricultural Science 19(2): 266-273

Soltys-Kalina D, Plich J, Strzelczyk-Żyta D, Śliwka J \& Marczewski W (2016). The effect of drought stress on the leaf relative water content and tuber yield of a half-sib family of 'Katahdin'-derived potato cultivars. Breeding Science 66(2): 328-331

Thomas C D, Cameron A, Green R E, Bakkenes M, Beaumont L J, Collingham Y C, Erasmus B F, De Siqueira M F, Grainger A \& Hannah L (2004). Extinction risk from climate change. Nature 427(6970): 145-148

Turinek M, Bavec M, Repič M, Turinek M, Krajnc A U, Möllers C, Tres A \& Bavec F (2016). Effects of intensive and alternative production systems on the technological and quality parameters of rapeseed seed (Brassica napus L.'Siska'). Journal of the Science of Food and Agriculture 97(8): 2647-2656

Ullah F, Bano A \& Nosheen A (2012). Effects of plant growth regulators on growth and oil quality of canola (Brassica napus L.) under drought stress. Pakistan Journal of Botany 44(6): 1873-1880

Wang Q, Yu Y, Li J, Wan Y, Huang Q, Guo Y \& Li H (2017). Effects of different forms of selenium fertilizers on Se accumulation, distribution, and residual effect in winter wheat-Summer maize rotation system. Journal of Agricultural and Food Chemistry 65(6): 1116-1123

White P, Bowen H, Parmaguru P, Fritz M, Spracklen W, Spiby R, Meacham M, Mead A, Harriman M \& Trueman L (2004). Interactions between selenium and sulphur nutrition in Arabidopsis thaliana. Journal of Experimental Botany 55(404): 1927-1937

Woo J \& Lim W (2017). Anticancer effect of selenium. Ewha Medical Journal 40(1): 17-21

$\mathrm{Xu} \mathrm{J} \mathrm{\&} \mathrm{Hu} \mathrm{Q} \mathrm{(2004).} \mathrm{Effect} \mathrm{of} \mathrm{foliar} \mathrm{application} \mathrm{of}$ selenium on the antioxidant activity of aqueous and ethanolic extracts of selenium-enriched rice. Journal of Agricultural and Food Chemistry 52(6): 1759-1763 